Tropical Journal of Pharmaceutical Research June 2017; 16 (6): 1299-1305

ISSN: $1596-5996$ (print); 1596-9827 (electronic)

(C) Pharmacotherapy Group, Faculty of Pharmacy, University of Benin, Benin City, 300001 Nigeria.

All rights reserved.

Available online at http://www.tjpr.org

Original Research Article

http://dx.doi.org/10.4314/tjpr.v16i6.13

\title{
Protective effect of grifolin against brain injury in an acute cerebral ischemia rat model
}

\author{
Shan Jing ${ }^{1,2}$, Piaopiao Ying ${ }^{3}$, Xiaohua $\mathrm{Hu}^{2}, \mathrm{Ze} \mathrm{Yu}^{2}$, Jianwei Sun ${ }^{2}$, Yuchao Ding ${ }^{2}$, \\ Hongyan $\mathrm{Du}^{2}$ and Shuijiang Song ${ }^{4 *}$ \\ ${ }^{1}$ Zhejiang University School of Medicine, Zhejiang 310058, ${ }^{2}$ Department of Neurological Rehabilitation, The Armed Police \\ Corps Hospital In Hangzhou, Zhejiang Province, Zhejiang $310051,{ }^{3}$ Clinical Laboratory, The Second Hospital Affiliated to \\ Zhejiang University School of Medicine, ${ }^{4}$ Department of Neurology, The Second Hospital Affiliated to Zhejiang University \\ School of Medicine, Zhejiang 310009, China
}

*For correspondence: Email: shuijiangsong@hotmail.com; Tel: 0086-0571-87783777

Revised accepted: 19 May 2017

\begin{abstract}
Purpose: To evaluate the protective effects of grifolin against brain injury in an acute cerebral ischemia rat model.

Methods: Rats were assigned to five groups: control, negative control, and grifolin (50, 100, and 200 $\mathrm{mg} / \mathrm{kg}$, p.o.) treated groups, which received the drug for 2 weeks. All the animals were sacrificed at the end of the protocol, and tissue homogenates were prepared from isolated brain tissue. Glutathione peroxidase (GPX), superoxide dismutase (SOD), malondialdehyde (MDA), and nitric oxide (NO), as oxidative stress indicators, were determined for the tissue homogenates of the ischemic rats. Inflammatory mediators (cytokines and nuclear factor kappa B p65, NF KB), DNA damage, and ATP and caspase 3 levels in the tissue homogenates were also assessed.

Results: Treatment with grifolin increased SOD and GPX significantly and decreased MDA and NO levels in tissue homogenates of the cerebral ischemic rats compared with those in the negative control group $(p<0.05)$. Treatment with grifolin also attenuated the altered levels of inflammatory mediators (cytokines and NF-KB), caspase 3, and ATP levels in the tissue homogenate of cerebral ischemic rats ( $p$ $<0.05$ ). The results of comet assay on the tissue homogenate suggest that treatment with grifolin reduced or prevented damage.

Conclusions: The results show that treatment with grifolin protects against neuronal damage in acute cerebral ischemic rats via its anti-inflammatory and anti-oxidant properties.
\end{abstract}

Keywords: Neuroprotection, Cerebral ischemia, Brain injury, DNA, Grifolin, Anti-oxidant

Tropical Journal of Pharmaceutical Research is indexed by Science Citation Index (SciSearch), Scopus, International Pharmaceutical Abstract, Chemical Abstracts, Embase, Index Copernicus, EBSCO, African Index Medicus, JournalSeek, Journal Citation Reports/Science Edition, Directory of Open Access Journals (DOAJ), African Journal Online, Bioline International, Open-J-Gate and Pharmacy Abstracts

\section{INTRODUCTION}

Stroke is a major cause of death worldwide [1]. The brain is a major organ and requires a large and constant blood supply to satisfy its metabolic demands. Thus, even a small alteration in blood flow to the brain results in neurological dysfunction and cerebral ischemia [2]. The pathogenesis of brain injury in cerebral ischemia involves enhanced apoptosis, inflammation, and redox imbalance [3]. It has also been reported that the condition worsens due to oxidative insults because they result in a decrease in the concentration of endogenous anti-oxidants and enhanced oxidative metabolic activity [4].

Previous reports have suggested that some "alternative" medicines, such as herbal extracts and natural products, show promising effects in the management of cerebral ischemia-induced 
injuries. Extracts of various plants, such as garlic, Ginkgo biloba, and Nigella sativa, showed beneficial effects against cerebral injury in experimental rat models [5,6]. Grifolin is a phenolic compound isolated from the Albatrellus ovinus mushroom [7]. There are reports that grifolin possesses potent anti-inflammatory and anti-cancer activities $[8,9]$. One study reported that grifolin inhibited the production of nitric oxide (NO) in LPS-stimulated RAW 264.7 cells [10]. It also inhibited the release of histamine from mast cells [11]. Moreover, it has been shown to possess anti-atherosclerotic activity and has been used in the management of cardiovascular disease [12]. In this study, we investigated the effects of grifolin in ischemia-induced cerebral injuries.

\section{EXPERIMENTAL}

\section{Animals}

Male albino Wistar rats (age: 8 weeks, weight: 230-280 g) were used for pharmacological screening in this study. All the animals were housed with a 12-h light/dark cycle at $25 \pm 2{ }^{\circ} \mathrm{C}$ and $60 \pm 5 \%$ humidity. Animals were fed a standard diet and water ad libitum. All experiments were approved by the Ethical Committee of The Second Hospital affiliated with Zhejiang University School of Medicine, China (approval no. TX136743), and the given study follows the guidelines of Association for the Assessment and Accreditation of Laboratory Animal Care International (AAALAC) for experimentation and animal use [13].

\section{Chemicals}

The Kunming Institute of Botany, China, provided the grifolin (> $99 \%$ purity, HPLC grade). Other chemicals were from Sigma-Aldrich (St. Louis, MO, USA).

\section{Evaluation of toxicity}

An acute toxicity study for grifolin was conducted according to the OECD 423 guideline. Grifolin was administered at different doses $(5,50,300$, and $2000 \mathrm{mg} / \mathrm{kg}$, p.o.) to the animals, which were observed closely for 2 weeks. All of the animals were observed for mortality and changes in behavior after 2 weeks of drug administration. It was found that grifolin at a dose of $2000 \mathrm{mg} / \mathrm{kg}$ was safe in the animals.

\section{Protocol design}

The animals were divided into five groups $(n=10$ each). The control group was sham-operated. In the negative control group, the ischemic group was 'treated' with vehicle alone. Grifolin-treated rats received 50,100 , or $200 \mathrm{mg} / \mathrm{kg}$, p.o., for 2 weeks. Then, ischemia was induced for $60 \mathrm{~min}$ and reperfusion was then allowed for a further 60 $\min [14]$.

\section{Induction of cerebral ischemia}

Animals were anesthetized with an injection of chloral hydrate $(360 \mathrm{mg} / \mathrm{kg}$, i.p.) and then subjected to ischemia-reperfusion. An incision was made in the neck to expose the carotid arteries. The exposed arteries were then clamped for $60 \mathrm{~min}$ to produce cerebral ischemia and then reperfusion was allowed to occur for 60 min after unclamping the arteries. To avoid hypothermia, the animals were maintained at 37 ${ }^{\circ} \mathrm{C}$.

\section{Tissue homogenates}

All animals were sacrificed by cervical dislocation after reperfusion. The brain was isolated by opening the cranial cavity. Ice-cold phosphate buffer solution was used to homogenize the brain tissue $(5 \mathrm{~mL}: 1 \mathrm{~g})$.

\section{Evaluation of oxidative stress parameters}

The principle of the assay depends on the reaction of MDA with thiobarbituric acid in an acidic medium when incubated for $45 \mathrm{~min}$ at 95 ${ }^{\circ} \mathrm{C}$. The concentration of MDA was estimated in the brain tissue homogenate by observing the absorbance at 520 and $535 \mathrm{~nm}$ using a spectrometer. The concentration of MDA in the brain tissue was considered to indicate the level of lipid peroxidation. A reported method was used to determine nitric oxide (NO). Here, the level of NO was estimated by observing nitrate to nitrite reduction at $540 \mathrm{~nm}$. A riboflavin-sensitized method was used to determine the activity of superoxide dismutase (SOD) in the tissue homogenate. Absorbance was observed for 4 min at $460 \mathrm{~nm}$. The method described by Paglia and Valentine was used for the determination of glutathione peroxidase (GPX) enzyme activity and the decrease in the optical density at a wavelength of $340 \mathrm{~nm}$ was considered to indicate the activity of the enzyme [14].

\section{Determination of cytokines}

Concentrations of TNF- $\alpha$ and IL-10 in the tissue homogenates were determined using ELISAs. In the protocols, the absorbance was observed at $450 \mathrm{~nm}$ for both cytokines [14].

Trop J Pharm Res, June 2017; 16(6): 1300 
Evaluation of nuclear factor-KB p65 (NF-KB p65)

An ELISA method was used to determine the NF-kB p65 in the tissue homogenate. A freezethaw cycle was used to break the cell membranes and the mix was centrifuged (5000 $x$ $g, 5 \mathrm{~min}, 2^{\circ} \mathrm{C}$ ). The supernatant was then removed for the assay. The optical density was determined at $450 \mathrm{~nm}$ [15].

\section{Determination of caspase-3 levels}

The level of caspase 3 was estimated using an ELISA kit. A microplate reader was used for the measurement of the final solution's absorbance at $450 \mathrm{~nm}$ [15].

\section{Assessment of ATP}

In the tissue homogenate, the level of ATP was determined using an ELISA. The optical density of the resulting solution was determined at 450 $\mathrm{nm}[15]$.

\section{Determination of DNA damage}

The comet assay was used to assess DNA damage. The tissue homogenate in PBS was stirred for $5 \mathrm{~min}$. Then, the tissue homogenate was filtered and $100 \mu \mathrm{L}$ of the cell suspension was mixed with agarose. The mixture was spread on an agarose pre-coated slide and DNA was unwound by placing it in an electrophoresis chamber (20 min, $180 \mathrm{~mA}, 25 \mathrm{~V})$. Then, $0.4 \mathrm{M}$ Tris- $\mathrm{HCl}$ buffer was used to wash the slides and they were stained with ethidium bromide solution. A fluorescence microscope was used to observe the DNA fragments on each slide. The Comet 5 imaging software (Kinetic Imaging Ltd., UK) was used to estimate cellular DNA damage [15].

\section{Statistical analysis}

Data are reported as mean \pm SD $(n=10)$ and were analyzed using one-way ANOVA (with Dunnett's post hoc test) using the GraphPad Prism software (ver. 3.0; San Diego, CA,
USA). The level of significance was set at $p<$ 0.05 .

\section{RESULTS}

The effects of grifolin on the parameters of oxidative stress are shown in Table 1. It shows that treatment with grifolin decreased the levels of MDA and NO significantly $(p<0.05$ and $p<0.01$, respectively) in the tissue homogenate of ischemic rats versus the negative control group. Moreover, the activities of GPX and SOD were enhanced significantly in the tissue homogenates from the grifolin-treated groups compared with those in the negative control group. The effect of grifolin on the parameters of oxidative stress was dose-dependent.

\section{Effect of grifolin on levels of cytokines}

There was a significant decrease in IL-10 and an increase TNF- $\alpha$ in the tissue homogenates of ischemic rats. Treatment with grifolin significantly enhanced the IL-10 and decreased the TNF- $\alpha$ levels in tissue homogenate versus those in the negative control group, in a dose-dependent manner (Figure 1).

\section{Effect of grifolin on NF-kB p65}

The effects of grifolin on the level of NF-KB p65 in the tissue homogenate of the ischemic rats are shown in Figure 2. There was a significant $(p<$ 0.01 ) decrease in the level of NF-KB p65 in grifolin-treated ischemic rats versus that in the negative control group.

\section{Effect of grifolin on caspase-3}

The level of caspase 3 was increased significantly in the tissue homogenate of ischemic rats in the negative control group versus that in the control group. Treatment with grifolin decreased the level of caspase 3 significantly $(p<0.01)$ in ischemic rats compared with that in the negative control group, in a dosedependent manner (Figure 3).

Table 1: Effect of grifolin on oxidative stress in tissue homogenates

\begin{tabular}{|c|c|c|c|c|}
\hline Group & $\begin{array}{c}\text { MDA } \\
\text { ( } \mu \mathrm{M} / 100 \mathrm{mg} \text { of } \\
\text { wet tissue) }\end{array}$ & $\begin{array}{c}\mathrm{NO} \\
\text { (mM/100 } \mathrm{mg} \text { of } \\
\text { wet tissue) }\end{array}$ & $\begin{array}{c}\text { SOD } \\
\text { (U/100 mg of wet } \\
\text { tissue) }\end{array}$ & $\begin{array}{c}\text { GPX } \\
\text { (U/ } 100 \mathrm{mg} \text { of } \\
\text { wet tissue) }\end{array}$ \\
\hline Control & $2.63 \pm 0.36$ & $8.87 \pm 0.75$ & $2.95 \pm 0.32$ & $182.4 \pm 11.2$ \\
\hline Negative control & $7.95 \pm 0.58^{\# \#}$ & $19.56 \pm 1.5^{\# \#}$ & $0.69 \pm 0.05^{\# \#}$ & $83.4 \pm 8.1^{\# \#}$ \\
\hline Grifolin (50 mg/kg) & $5.87 \pm 0.25^{\star}$ & $15.4 \pm 0.61^{*}$ & $1.1 \pm 0.12^{\star *}$ & $99.5 \pm 7.5^{\star *}$ \\
\hline Grifolin (100 mg/kg) & $4.15 \pm 0.11^{\star *}$ & $12.9 \pm 0.83^{\star *}$ & $1.85 \pm 0.28^{* *}$ & $137.2 \pm 10.1^{* *}$ \\
\hline Grifolin (200 mg/kg) & $3.26 \pm 0.15^{\star *}$ & $10.3 \pm 0.47^{\star *}$ & $2.37 \pm 0.41^{* *}$ & $159.8 \pm 13.4^{\star *}$ \\
\hline
\end{tabular}



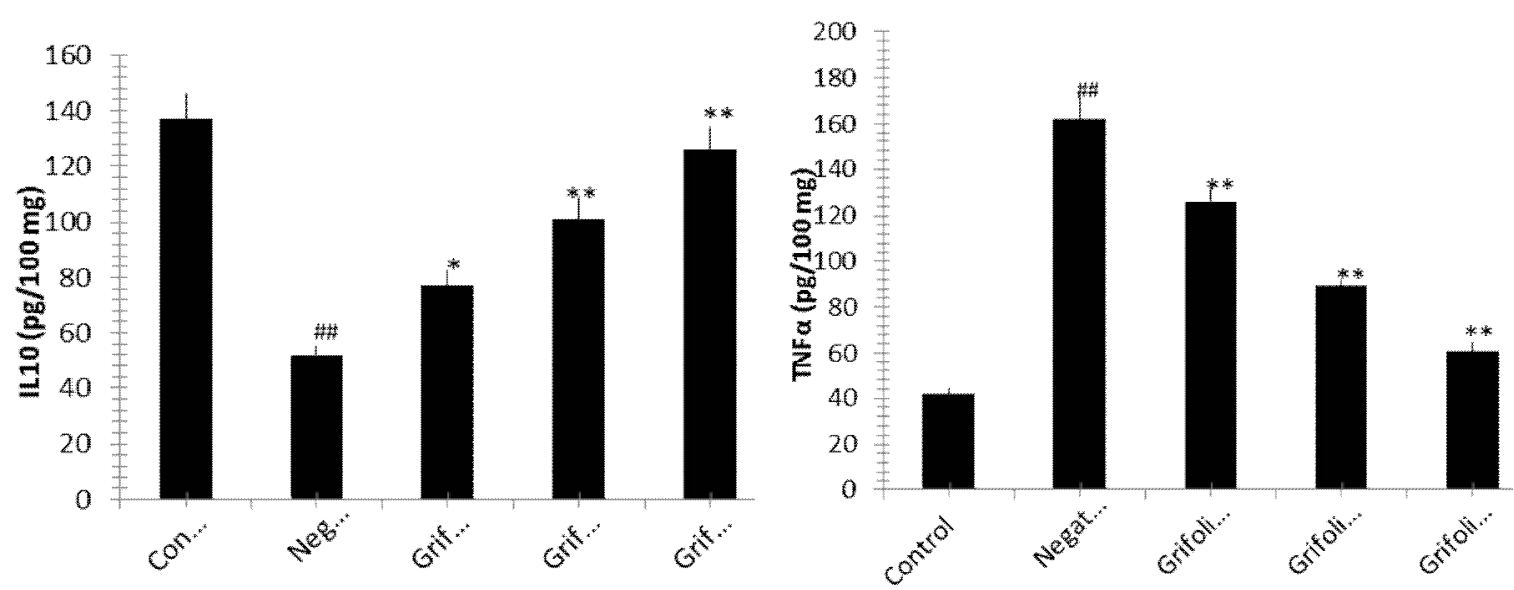

Figure 1: Effect of grifolin on cytokines in the tissue homogenate. Data are presented as means \pm SDs $(n=10) .{ }^{\# \#} p<0.01$, vs. control, * $p<0.05,{ }^{* *} p<0.01$, vs. the negative control

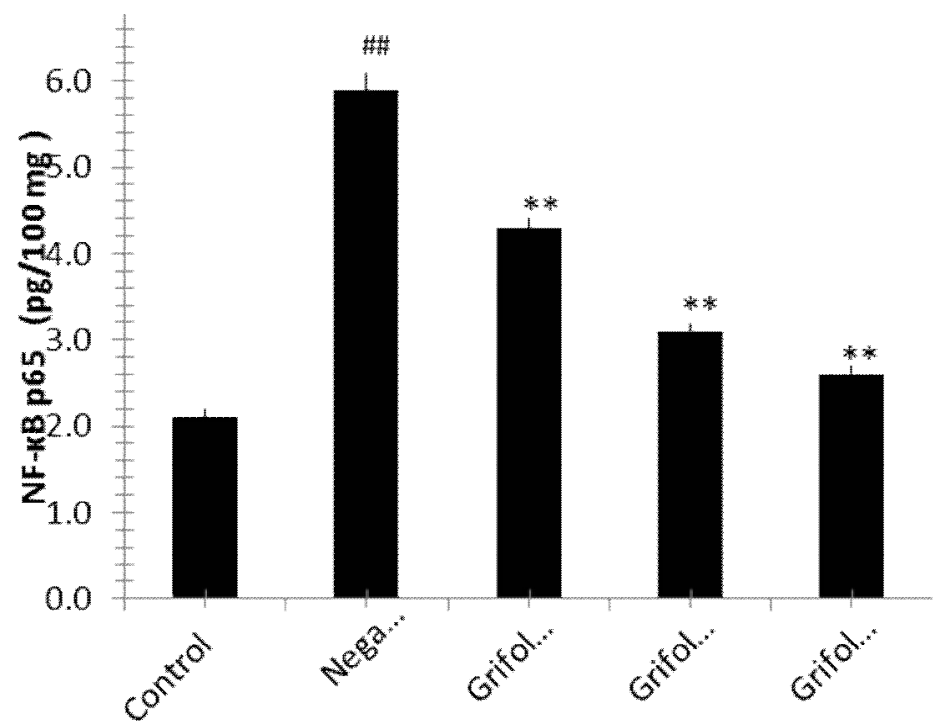

Figure 2: Effects of grifolin on the level of NF-kB p65 in tissue homogenate. Data are presented as means \pm SDs $(n=10)$. ${ }^{\#} p<0.01$, vs. control, ${ }^{*} p<0.05,{ }^{*}{ }^{*} p<0.01$, vs. the negative control

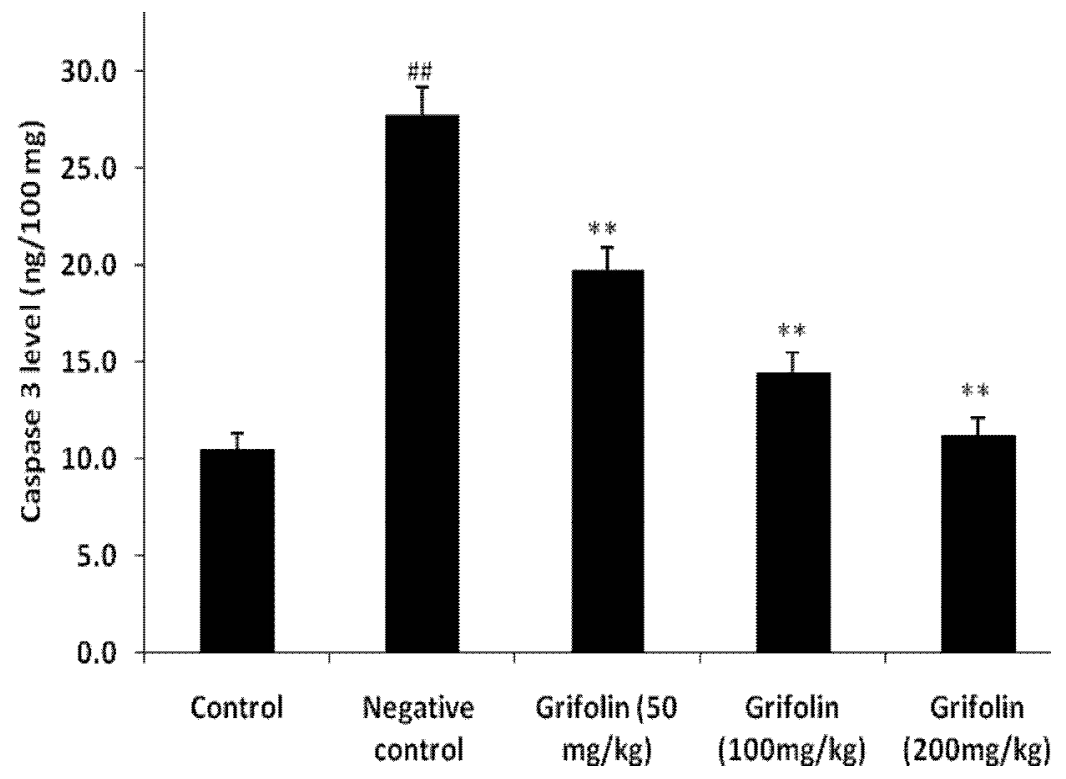

Figure 3: Effect of grifolin on caspase 3 in tissue homogenates. Data are presented as means $\pm \operatorname{SDs}(n=10)$. \# $p<0.01$, vs. control, ${ }^{*} p<0.05,{ }^{* *} p<0.01$, vs. the negative control 


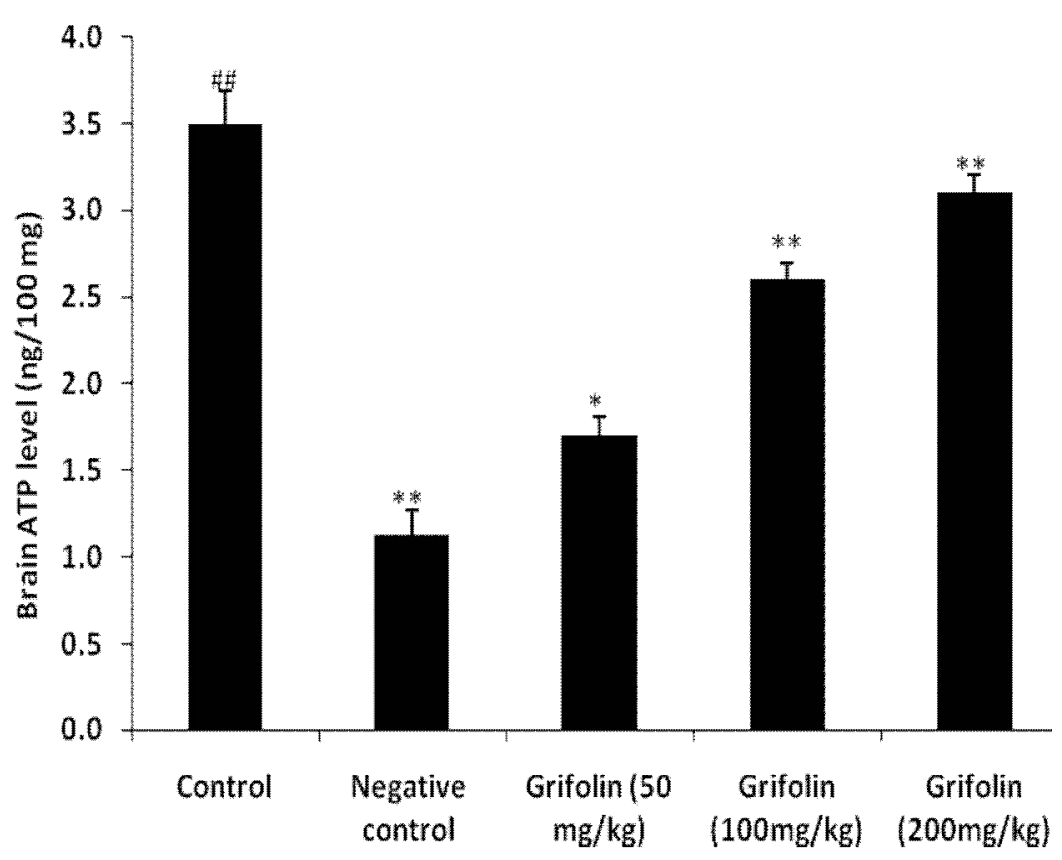

Figure 4: Effect of grifolin on ATP levels in tissue homogenates. Data are presented as means \pm SDs $(n=10)$. \#\# $p<0.01$, vs. control, ${ }^{*} p<0.05,{ }^{* *} p<0.01$, vs. negative control

\section{Effect of grifolin on ATP levels}

Ischemia resulted in a decrease in the brain ATP level in the negative control group compared with that in the control group (Figure 4). There was a significant increase $(p<0.05, p<0.01)$ in the brain ATP level in the grifolin-treated groups versus that in the negative control group in a dose-dependent manner.

\section{Effect of grifolin on DNA damage}

The comet assay was used to estimate the effects of grifolin on DNA damage in tissue homogenate (Figure 5). DNA damage was evaluated by estimating the tail moment, DNA tail, the length of the tail, and the percentage of tailed and untailed cells with extracted cellular DNA. There were significant increases $(p<0.01)$ in the percentage of untailed cells and a decrease in the percentage of tailed cells in the grifolin-treated groups versus the negative control group. Additionally, treatment with grifolin significantly decreased the tail moment, DNA tailing, and tail length in the ischemic rats versus those in the negative control group.

\section{DISCUSSION}

Neuronal cell degeneration in cerebral ischemia results from enhanced levels of cytokines and oxidative stress. Ischemia, like other pathological conditions, disturbs homeostasis. In this study, we evaluated the effects of grifolin in cerebral ischemic conditions and also suggest its possible mechanism of action.

There are several reports claiming that ischemic/reperfusion conditions enhance oxidative stress, thereby damaging cellular proteins and nucleic acids [16]. The result of another study showed that grifolin reduced oxidative stress, attenuating the changes in various parameters reflecting it. Ischemia has also been reported to increase the production of inflammatory mediators [17]. The present study suggested that grifolin significantly decreased inflammatory mediators in ischemic rats versus those in the negative control group.

Apoptosis is activated by increased caspase 3 activity [18]. Apoptosis in a tissue also disturbs mitochondrial function, such as ATP production. Treatment with grifolin decreased the activity of caspase 3 and the level of ATP in the tissue homogenate of ischemic rats versus those in the negative control group. This resulted in protection from DNA damage in the grifolintreated ischemic rats compared with the status in the negative control animals

\section{CONCLUSION}

From the present study, we conclude that grifolin protects neurons in acute cerebral ischemia. Specifically, it inhibits the process of apoptosis through its anti-inflammatory and anti-oxidant properties. 

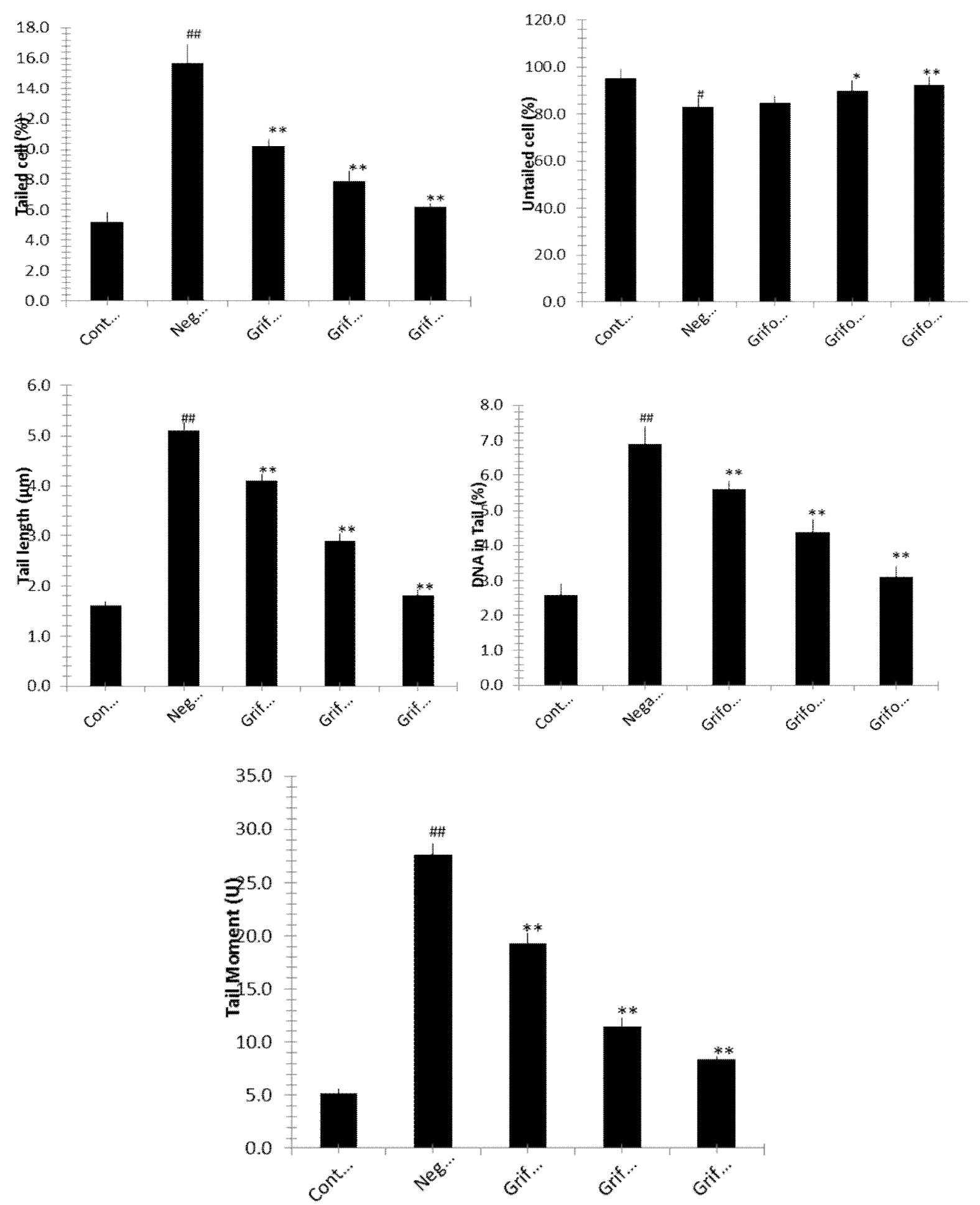

Figure 5: Effects of grifolin on DNA damage, as determined by the comet assay. Data are presented as means \pm SDs $(n=10) .{ }^{\# \#} p<0.01$, vs. control, ${ }^{*} p<0.05$, ${ }^{* *} p<0.01$, vs. negative control

\section{DECLARATIONS}

\section{Acknowledgement}

The authors acknowledge that this study was supported by Second Hospital Affiliated to Zhejiang University School of Medicine.

\section{Conflict of Interest}

No conflict of interest associated with this work.

\section{Contribution of Authors}

The authors declare that this work was done by 
the authors named in this article and all liabilities pertaining to claims relating to the content of this article will be borne by them.

\section{Open Access}

This is an Open Access article that uses a funding model which does not charge readers or their institutions for access and distributed under the terms of the Creative Commons Attribution License (http://creativecommons.org/licenses/by/ 4.0) and the Budapest Open Access Initiative (http://www.budapestopenaccessinitiative.org/rea d), which permit unrestricted use, distribution, and reproduction in any medium, provided the original work is properly credited.

\section{REFERENCES}

1. Nukata M, Hashimoto T, Yamamoto I, Iwasaki N, Tanaka $M$, Asakawa $Y$. Neogrifolin derivatives possessing antioxidative activity from the mushroom Albatrellus ovinus. Phytochem 2002; 59: 731-737.

2. Quang DN, Hashimoto $T$, Arakawa $Y$, Kohchi $C$, Nishizawa $T$, Soma $G$. Grifolin derivatives from Albatrellus caeruleoporus, new inhibitors of nitric oxide production in RAW 264.7 cells. Bioorg Med Chem 2006; 14: 164-168.

3. Ye M, Liu JK, Lu ZX, Zhao Y, Liu S, Li L, Tan M, Weng X, $L i W$, Cao $Y$. Grifolin, a potential antitumor natural product from the mushroom Albatrellus confluens, inhibits tumor cell growth by inducing apoptosis in vitro. FEBS Letters, 2005; 579: 3437-3443.

4. Guillamón E, García-Lafuente A, Lozano M, Lozano M, D'Arrigo $M$, Rostagno MA, Villares $A$, Martínez $J A$. Edible mushrooms: role in the prevention of cardiovascular diseases. Fitoterapia 2010; 81: 715-723.

5. El-Enshasy $H$, Daba A, El-Demellawy M, Ibrahim A, El Sayed S, El-Badry I. Bioprocess development for large scale production of anticancer exo-polysaccharide by Pleurotus ostreatus in submerged culture. J Appl Sci. 2010; 10: 2523-2529.

6. Yeh JY, Hsieh LH, Wu KT, Tsai CF, Antioxidant properties and antioxidant compounds of various extracts from the edible basidiomycete Grifola frondosa (Maitake). Molecules 2011; 16: 3197-3211.
7. Moskowitz MA, Lo EH, Ladecola C. The science of stroke: mechanisms in search of treatments. Neuron 2010; 67: 181-198.

8. Deb $P$, Sharma $S$, Hassan KM. Pathophysiologic mechanisms of acute ischemic stroke: an overview with emphasis on therapeutic significance beyond thrombolysis. Pathophysiology 2010; 17: 197-218.

9. Yousuf S, Atif F, Ahmad M, Hoda N, Ishrat T, Khan B, et al. Resveratrol exerts its neuroprotective effect by modulating mitochondrial dysfunctions and associated cell death during cerebral ischemia. Brain Res 2009; 1250: 242-253.

10. Chan $\mathrm{PH}$. Reactive oxygen radicals in signaling and damage in the ischemic brain. J Cereb Blood Flow Metab 2001; 21: 2-14.

11. Aguilera $P$, Chánez-Cárdenas ME, Ortiz-Plata A, LeónAparicio D, Barrera D, Espinoza-Rojo $M$, et al. Aged garlic extract delays the appearance of infarct area in a cerebral ischemia model, an effect likely conditioned by the cellular antioxidant systems. Phytomedicine 2010; 17: $241-247$

12. Takayasu Y, Nakaki J, Kawasaki T, Koda K, Ago Y, Baba A, Matsuda T. Edaravone, a radical scavenger, inhibits mitochondrial permeability transition pore in rat brain. $J$ Pharmacol Sci. 2007; 103: 434 - 437.

13. Guide for the Care and Use of Laboratory Animals: Eighth Edition Committee for the Update of the Guide for the Care and Use of Laboratory Animals; National Research Council. 2010; ISBN: 0-309-15401-4.

14. Ahmed MA, El Morsy EM, Ahmed AA. Pomegranate extract protects against cerebral ischemia/reperfusion injury and preserves brain DNA integrity in rats. Life Sci. 2014; 110(2): 61-69.

15. Li YH, Jiang B, Zhang T, Mu WM, Liu J. Antioxidant and free radical-scavenging activities of chickpea protein hydrolysate (CPH). Food Chem. 2008; 106: 444 - 450.

16. Tang NY, Liu CH, Hsieh CT, Hsieh CL. The antiinflammatory effect of paeoniflorin on cerebral infarction induced by ischemia-reperfusion injury in SpragueDawley rats. Am J Chin Med. 2010; 38: 51-64.

17. Li J, Han B, Ma X, Qi S. The effects of propofol on hippocampal caspase-3 and Bcl-2 expression following forebrain ischemia-reperfusion in rats. Brain Res 2010; 1356: 11-23. 